OPEN ACCESS

Edited by:

Xiaoping Yuan,

GFZ German Research Centre for

Geosciences, Germany

Reviewed by:

Lei Wu,

Zhejiang University, China

Maodu Yan,

Institute of Tibetan Plateau Research

(CAS), China

*Correspondence:

Jin Liu

358198000@qq.com

Specialty section:

This article was submitted to

Structural Geology and Tectonics,

a section of the journal

Frontiers in Earth Science

Received: 23 November 2021 Accepted: 22 December 2021

Published: 18 January 2022

Citation:

Liu J, Wang P, Chen X, Shi W, Song L and Hu J (2022) The Changes in Drainage Systems of Weihe Basin and Sanmenxia Basin Since Late Pliocene Give New Insights Into the Evolution of the Yellow River.

Front. Earth Sci. 9:820674. doi: 10.3389/feart.2021.820674

\section{The Changes in Drainage Systems of Weihe Basin and Sanmenxia Basin Since Late Pliocene Give New Insights Into the Evolution of the Yellow River}

\author{
Jin Liu ${ }^{1 *}$, Ping Wang ${ }^{2}$, Xingqiang Chen ${ }^{3}$, Wei Shi ${ }^{4}$, Lijun Song ${ }^{5}$ and Jianmin $\mathrm{Hu}^{4}$ \\ ${ }^{1}$ School of Civil and Architecture Engineering, Xi'an Technological University, Xi'an, China, ${ }^{2}$ School of Geography, Nanjing Normal \\ University, Nanjing, China, ${ }^{3}$ China Railway First Survey \& Design Institute Group Co., Ltd., Xi'an, China, ${ }^{4}$ Institute of \\ Geomechanics, Chinese Academy of Geological Sciences, Beijing, China, ${ }^{5}$ School of Earth Sciences and Engineering, Xi'an \\ Shiyou University, Xi'an, China
}

The formation of the Yellow River involved the draining of a series of ancestral local lakes along their course, substantially changing the regional, geomorphic, and paleoenvironmental evolution. However, the evolution of the Weihe-Sanmenxia Basin section of the Yellow River remains indistinct as previous studies regard the Weihe and Sanmenxia Basin as one integral basin of the Late Cenozoic. Here, we present the detrital zircon age spectra from the Pliocene-Pleistocene Sanmen Formation to clarify the drainage system evolution of the two basins since the Late Pliocene. The results reveal that these two basins belonged to different drainage systems in the Late Pliocene because no sediments from the marginal mountains of the Weihe Basin accumulated in the Sanmenxia Basin. At 2.8/2.6 Ma, the currents presented at the edge of the basins and transported the sediment of east Hua Mountain into the Sanmenxia Basin, where it was deposited. This integration likely leads to a mismatch between the deposition and regional paleoclimate in previous studies. At 1.0 Ma, the Sanmenxia Gorge was traversed and the Yellow River finally formed, depositing Jinshaan Gorge sediment into the Sanmenxia Basin and lower reaches of the Yellow River.

Keywords: Yellow river (Huanghe), Sanmen Fm., Sanmenxia Basin, Weihe Basin, river formation

\section{INTRODUCTION}

The Yellow River is the second-longest river in China and the sixth-longest river in the world. Previous studies suggested that the Yellow River achieved its present geometry by integrating a series of ancestral local drainages (Craddock et al., 2010; Pan et al., 2012) and has long been related to the uplift of the northeastern Tibetan Plateau (Wang et al., 2013; Xiao et al., 2020).

In the middle reaches of the Yellow River, many studies have been carried out in Jinshaan Gorge (Fu et al., 2013; Hu et al., 2017) and Sanmenxia Gorge (Wang et al., 2002; Pan et al., 2005; Jiang et al., 2007; Zheng et al., 2007; Kong et al., 2014; Hu et al., 2016). Jinshaan Gorge connects the Hetao Basin and Weihe Basin, whereas Sanmenxia Gorge connects Weihe Basin and Huabei Plain. However, the integration of the Weihe Basin and Sanmenxia Basin remains indistinct, which makes the Yellow River bend significantly (nearly $90^{\circ}$ ) in Tongguan County (Figure 1).

Previous studies have regarded the Weihe Basin and Sanmenxia Basin as one integral basin, belonging to the Sanmen Paleolake since $\sim 5 \mathrm{Ma}$, having been deposited with the fluvio- 

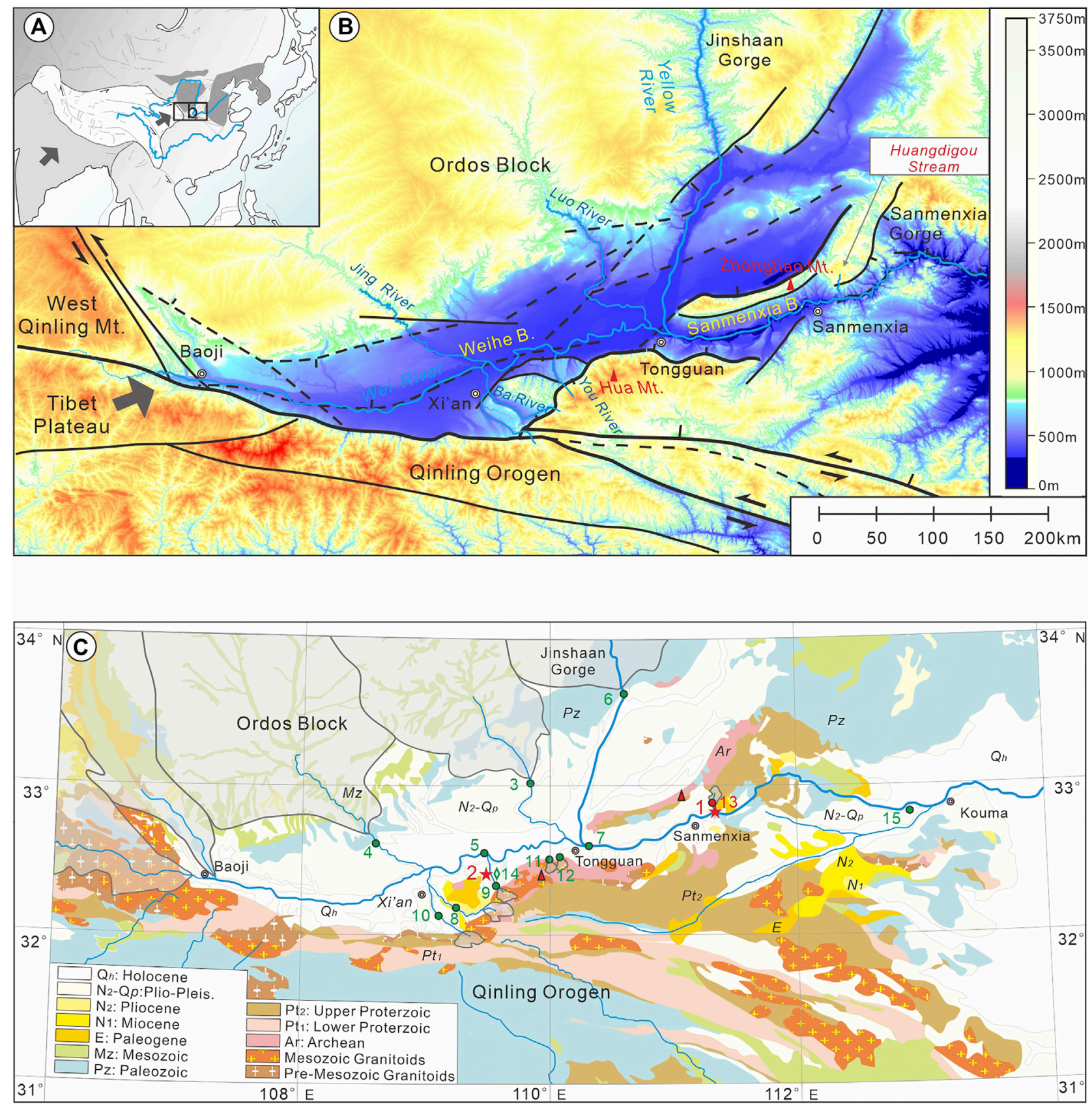

FIGURE 1 | (A), Locating of the Yellow River and the study area. (B), Tectonic setting and geomorphic features of the Weihe Basin and Sanmenxia Basin. (C), Lithostratigraphy of the study area and the sampling location. The stars indicate the study site in this article (1. Huangdigou section; 2. Songjiabeigou section). The open circles and numbers are the locations of published modern river samples, and the diamonds indicate the locations of the sites of previously studied samples from basin or terrace sediments (see Supplementary Table $\mathbf{S 1}$ for sample information).

lacustrine Sanmen Formation (Sm Fm.) (Wang et al., 2004; Wang et al., 2013). However, the Sm Fm. in these two basins show different sedimentary characteristics and are considered to have different deposition locations. The paleogeomorphic study (Zhu, 1989) and sedimentary facies of drilled cores (Liu and Zhou, 2015) indicated that the Weihe Basin and Sanmenxia Basin were isolated during the Pliocene but belonged to the same Sanmen Paleolake during the Early Pleistocene (Han et al., 2002). To determine that the Weihe Basin and Sanmenxia Basin belong to the same drainage system at $5 \mathrm{Ma}$ or Early Pleistocene, the sedimentary character of the Sm Fm. should be studied. Because the Weihe Basin is located upstream and the Sanmenxia Basin is located downstream, once the two basins are integrated, the 


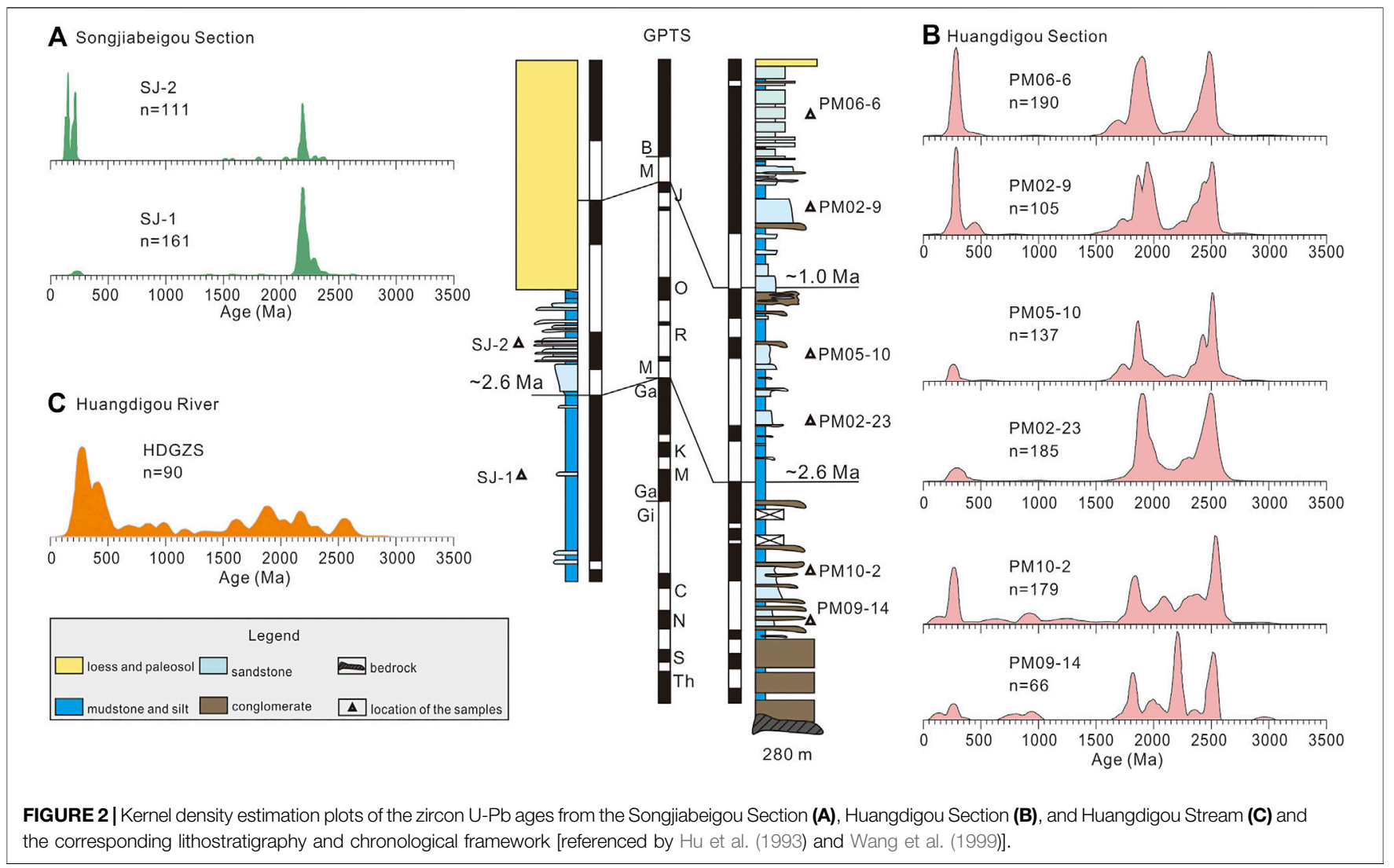

water in the Weihe Basin will flow into the Sanmenxia Basin, resulting in sedimentary facies and provenance of the Sm Fm. in the two basins changed simultaneously. Studies of sedimentary facies and heavy minerals in the Sm Fm. of the Huangdigou section in the Sanmenxia Basin and Songjiabeigou section in the Weihe Basin have been carried out in our previous studies (Liu et al., 2019; Liu et al., 2020). Based on the reported paleomagnetic ages (Hu et al., 1993; Wang et al., 1999) and our previous work, the sections could be divided into five and three sediment environments in the Sanmenxia Basin and Weihe Basin, respectively. The Huangdigou section consists mainly of gray conglomerates, yellowish sands, green or yellowish mud, and minor yellow silt and could be divided into alluvial fan $(\sim 5-2.8 \mathrm{Ma})$, a shallow lake $(\sim 2.8-1.8 \mathrm{Ma})$, a lake shore environment $(\sim 1.8-1.0 \mathrm{Ma})$, a fluvial setting $(\sim 1.0-0.15 \mathrm{Ma})$, and eolian loess (younger than $\sim 0.15 \mathrm{Ma}$ ) from bottom to top. The Songjiabeigou section contains mainly yellowish sand and green and blue clay, which can be divided into deep lake environment (prior $\sim 2.6 \mathrm{Ma}$ ), fluvial environment ( 2.6-1.5 Ma), and eolian loess (younger than $\sim 1.5 \mathrm{Ma}$ ) from bottom to top. However, the single-grain zircon $\mathrm{U}-\mathrm{Pb}$ age spectra, a diagnostic tool for identifying the source areas in East Asia (e.g., Stevens et al., 2013; Nie et al., 2015; Licht et al., 2016), are still poorly understood. In this study, we measured nine detrital zircon ages from two well-dated sections and one from Huangdigou Stream to represent sediment from Zhongtiao Mountain and compared the results with published zircon ages of the modern river sand samples to determine the evolution of the basin drainage system.

\section{MATERIALS AND METHODS}

Clastic deposits started to be accumulated in the Weihe and Sanmenxia Basins since the Paleogene (Chen et al., 2021). Extensive fluvial-lacustrine Sanmen Formation was developed continuously since the Late Pliocene (Wang et al., 2013), providing reliable material for the basin paleoenvironmental evolution research. The different lithology and chronology of the surrounding mountains make the region an ideal site for tracing the provenance (see detailed information from Supplementary Figure S1).

In the field, we explored the Songjiabeigou section $\left(109^{\circ} 30^{\prime} 43^{\prime \prime} \mathrm{E}, 34^{\circ} 25^{\prime} 53^{\prime \prime} \mathrm{N}\right)$ and the Huangdigou section $\left(111^{\circ} 16^{\prime} 54^{\prime \prime}-111^{\circ} 16^{\prime} 56^{\prime \prime} \mathrm{E}, 34^{\circ} 49^{\prime} 38^{\prime \prime}-34^{\circ} 49^{\prime} 48^{\prime \prime} \mathrm{N}\right)$ in the Weihe and Sanmenxia Basins, respectively. Nine samples were collected from the coarse channel or floodplain deposits of these two basins. Six of them were from the Huangdigou section of the Sanmenxia Basin (two from the lower Sm Fm. and four from the upper Sm Fm.) and two from the Songjiabeigou section of the Weihe Basin (one from the lower Sm Fm. and one from the upper $\mathrm{Sm}$ Fm.) (see the positions of the samples in Figure 2). Another sample was collected from the modern stream sediment in Huangdigou Stream (shown in Figure 1) to represent the provenance of Zhongtiao Mountain. 


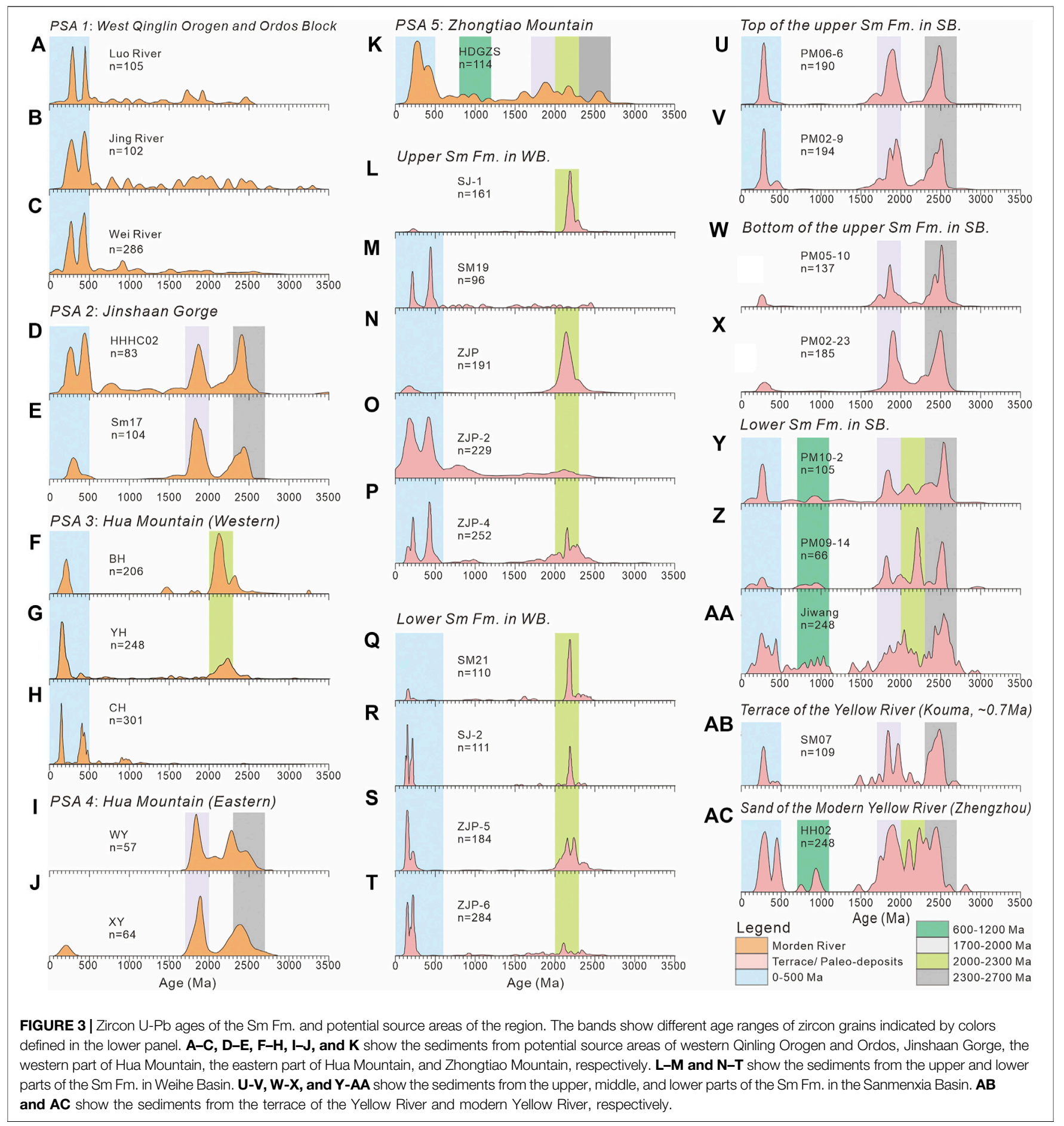

\section{RESULTS OF THE DETRITAL ZIRCON U-PB GEOCHRONOLOGY}

The $\mathrm{U}-\mathrm{Pb}$ ages of each sample are presented by kernel density estimation in Figure 2 using the DensityPlotter software (Vermeesch, 2012). These large age clusters indicate that the grains in these samples were derived from a number of heterogeneous and varying sources. In Sanmenxia Basin, the lower Sm Fm. (PM09-14 and PM10-2) show eight age clusters at $\sim 100 \mathrm{Ma}, \sim 250 \mathrm{Ma}, \sim 800 \mathrm{Ma}, \sim 950 \mathrm{Ma}, \sim 1,800 \mathrm{Ma}$, $\sim 2,000 \mathrm{Ma}, \sim 2,200 \mathrm{Ma}$, and $\sim 2,500 \mathrm{Ma}$, with four large peaks at $\sim 250 \mathrm{Ma}, \sim 1,800 \mathrm{Ma}, \sim 2,200 \mathrm{Ma}$, and $\sim 2,500 \mathrm{Ma}$. However, the upper Sm Fm. can be divided into two units: the bottom of the formation (PM05-10 and PM02-23) exhibits two age clusters at $\sim 1,800 \mathrm{Ma}$ and $\sim 2,500 \mathrm{Ma}$, whereas the top of the formation (PM $02-9$, PM 06-6) shows three obvious clusters at $\sim 250 \mathrm{Ma}$, 
$\sim 1,800 \mathrm{Ma}$, and $\sim 2,500 \mathrm{Ma}$. Nevertheless, in the Weihe Basin, the data for the lower (SJ1) and upper Sm Fm. (SJ2) show the same pattern, with no more than/only two clusters at $\sim 250 \mathrm{Ma}$ and $\sim 2,200 \mathrm{Ma}$, but with a different ratio. SJ2 sediment consists of younger age components, which account for approximately $28 \%$ of the sediment, whereas SJ1 accounts for approximately 3\%.

The modern fluvial sample HDGZS-1 shows one distinct peak at $\sim 250 \mathrm{Ma}$ and four small clusters at $\sim 900 \mathrm{Ma}, \sim 1,800 \mathrm{Ma}$, $\sim 2,200 \mathrm{Ma}$, and $\sim 2,600 \mathrm{Ma}$. See detailed chronologies in Supplementary Table S2.

\section{AGE COMPARISON AND INTERPRETATION OF THE POTENTIAL SOURCE AREAS}

Detrital zircon $\mathrm{U}-\mathrm{Pb}$ geochronology has long been regarded as a powerful tool to constrain the provenance of terrigenous sediments and the evolution of sedimentary basins (Dickinson et al., 1983; Gehrels et al., 2003; Zheng et al., 2020; Shang et al., 2021). Comparing zircon ages with sediments that accumulate from potential source areas could provide a comprehensive view of potential source areas (Gehrels, 2012). Rivers can mix all the bedrock lithology of potential sources (He et al., 2013), and analyses of modern river sands can be used to reflect the comprehensive characteristics of potential source areas and help track the long-term evolution of the region (Nie et al., 2012; Chen et al., 2017). Therefore, in order to better determine the provenance changes, published detrital zircon $\mathrm{U}-\mathrm{Pb}$ ages in modern river sediments were compiled and compared with our studies (Supplementary Table S1, Figure 3).

From Figure 3, the provenance of the western Qinling Orogen and Ordos Block, represented by the modern Luo River and Jing River (Zhang et al., 2019) and Wei River (Zhang et al., 2021), shows obvious clusters at $\sim 250 \mathrm{Ma}$ and $\sim 450 \mathrm{Ma}$. The zircon spectrum of modern Yellow River sediments, collected at Hancheng (HHHC02, Yang et al., 2009) and Tongguan (SM 17, Kong et al., 2014), demonstrates great similarities with three clusters at $\sim 250 \mathrm{Ma}, \sim 1,800 \mathrm{Ma}$, and $\sim 2,500 \mathrm{Ma}$ and are regarded as the provenance character of the Jinshaan Gorge. The sediments from the Ba River, You River, and Chan River (BH, Zhang et al., 2018; YH and $\mathrm{CH}$, Zhang et al., 2021), which originate from western Hua Mountain, show two distinct peaks at $\sim 150 \mathrm{Ma}$ and $\sim 2,200 \mathrm{Ma}$. In addition, the sediments from two valleys (WY and $\mathrm{XY}$ ) at the eastern Hua Mountain exhibit two obvious age peaks at 1,800 Ma and 2,200 Ma (Zhang, 2008). The sediments from Huangdigou Valley of Zhongtiao Mountain show five age ranges: $\sim 250 \mathrm{Ma}, \sim 900 \mathrm{Ma}, \sim 1,800 \mathrm{Ma}, \sim 2,200 \mathrm{Ma}$, and 2,600 Ma.

From the $\mathrm{U}-\mathrm{Pb}$ age spectrum of different potential provenance regions, sediments from the western Qinling Orogen and Ordos Block are relatively young and seldom contain old zircon. Sediments from western Hua Mountain and Zhongtiao Mountain contain an age peak at $\sim 2,200 \mathrm{Ma}$, which is absent in modern Yellow River sediments. The North China Craton formed at $\sim 2,500 \mathrm{Ma}$; thus, the regional zircon spectrum revealed the peak at 2,300 2,700 Ma widespread. At approximately $\sim 2,200 \mathrm{Ma}$, the region experienced a long-term magma quiet period (Zhai and Peng, 2007) with occasional rifting, accretion, and collision processes in Zhongtiao Mountain and Hua Mountain (Zhai and Santosh, 2011; Du et al., 2016; Peng et al., 2017; Du et al., 2018). This indicated that the sediment with a peak at $\sim 2,200 \mathrm{Ma}$ could be regarded as a representative feature of the Zhongtiao Mountain and Hua Mountain provenance. These differences make it possible to identify potential provenance regions by the $\mathrm{U}-\mathrm{Pb}$ age.

The spectrum characteristics of potential provenance regions were compared with those of Sm Fm. to trace the provenance. The sediments of Sm Fm. in the Weihe Basin were mainly from the western areas of the Hua Mountain, with no obvious changes. For Sanmenxia Basin, there were two provenance shifts at $2.8 \mathrm{Ma}$ and $1.0 \mathrm{Ma}$, respectively. At $2.8 \mathrm{Ma}$, the sediments changed from Zhongtiao Mountain to eastern Hua Mountain, indicating that the sediment provenance changed from near-source deposition to west of the Weihe Basin. This implies that water from the Weihe Basin began to flow into the Sanmenxia Basin. At $1.0 \mathrm{Ma}$, sediments are very similar to the modern Yellow River, indicating that the Jinshaan Gorge drainage system was connected to the region (Figure 4). This hypothesis is also supported by the evolution of the Yellow River in the Jinshaan Gorge, which revealed that the final incision of Jinshaan Gorge was $\sim 1.2 \mathrm{Ma}$ (Hu et al., 2016). Following the Yellow River formation, the sediment discharged by the Wei River occupied only about $30 \%$ of the Yellow River (Zhang et al., 2018); therefore, the sediment in the Sanmenxia Basin did not exhibit many Weihe Basin characteristics.

\section{DISCUSSION}

\section{The Timing of the Connection of the Weihe and the Sanmenxia Basins}

The apparent difference in sediment provenance in the Sanmenxia and Weihe Basins before $2.8 \mathrm{Ma}$ indicated that they belonged to different drainage systems. Previous studies of the sedimentary facies (Liu et al., 2019) indicated that the lake level in the Weihe Basin decreased, whereas in the Sanmenxia Basin, the level increased at $2.8 \mathrm{Ma}$; this study further revealed that the sediment provenance of the Sanmenxia Basin changed from Zhongtiao Mountain to eastern Hua Mountain. The zircon ages verified that a paleocurrent originated from the eastern Hua Mountain and transported the sediments into the Sanmenxia Basin at 2.8 Ma. Thus, we regarded the two basins as belonging to the same Paleo-Sanmen Lake drainage system not earlier than $2.8 \mathrm{Ma}$. After the connection of drainage systems, a great volume of water in Weihe Basin flowed into the Sanmenxia Basin, therefore explaining the formation of the oldest terrace $(\sim 2.6 \mathrm{Ma})$ in Weihe Basin (Sun, 2005). Moreover, this connection resulted in a decrease in regional erosion, which may prompt the traversing of Jinshaan Gorge. 


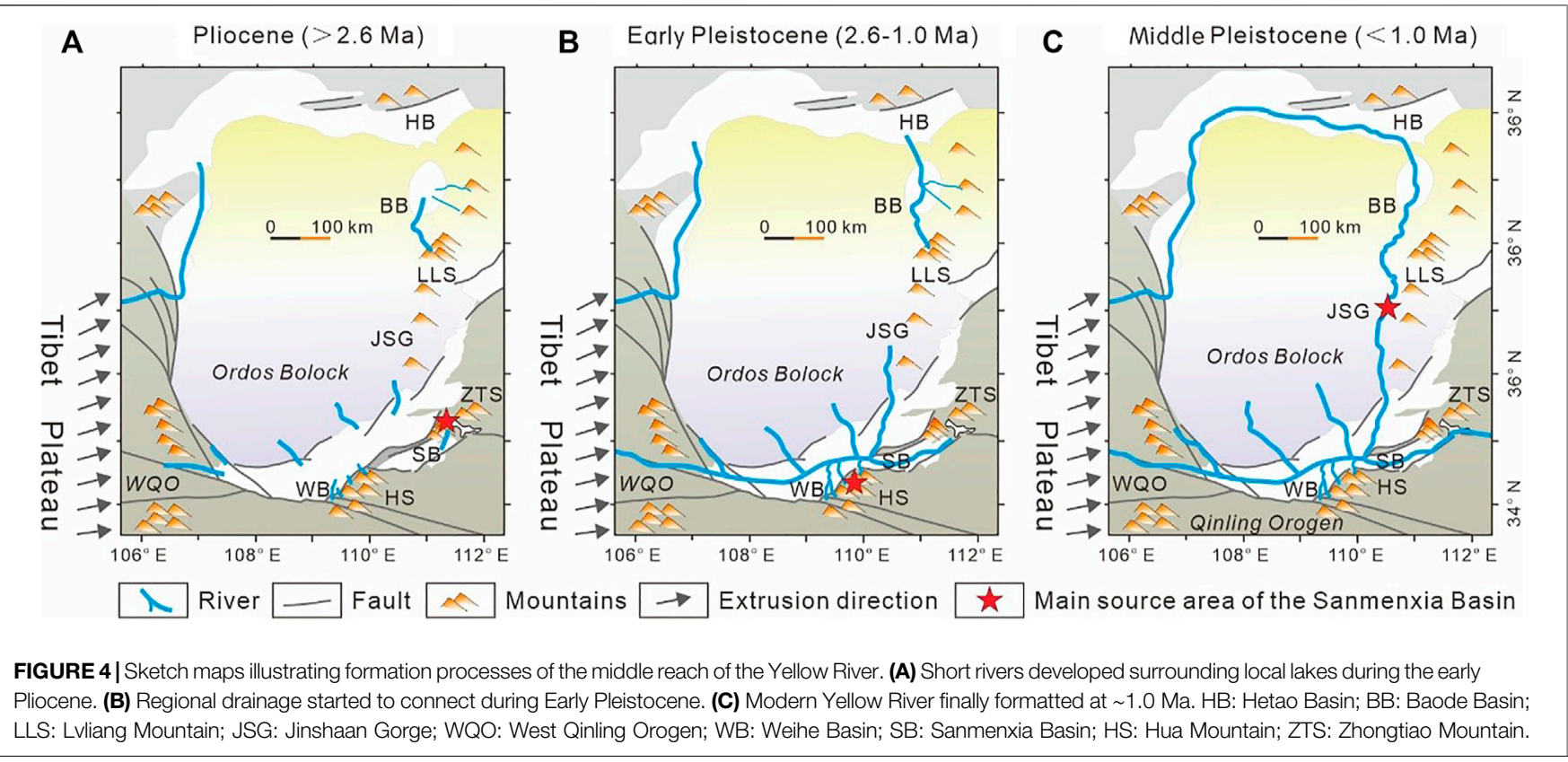

\section{Implication for the Formation of the Modern Yellow River}

The traversal of the Sanmenxia Gorge is regarded as the final formation of the Yellow River (Pan et al., 2005; Jiang et al., 2007; Wang et al., 2016). However, this date is still debated, from Early Pleistocene (Xue, 1996; Yang et al., 2001) to 1.2 Ma (Zhu, 1989; Pan et al., 2005; Fu et al., 2008; Pan et al., 2012; Hu et al., 2017) or even 0.15 Ma (Wang et al., 2002; Jiang et al., 2007). The sediment of the Sanmenxia Basin after 1.0 Ma shows great consistency with Jinshaan Gorge (HHHC02; Yang et al., 2009), Tongguan County (SM17; Kong et al., 2014), and Yellow River terrace with the age of 0.7 Ma (SM07; Kong et al., 2014) (Figure 3). The studies of the detrital zircon $\mathrm{U}-\mathrm{Pb}$ ages in the Sanmenxia Basin indicate that the traversing time of the Sanmenxia Gorge is $\sim 1.0 \mathrm{Ma}$. This conclusion reveals that the sedimentary facies in the Sanmenxia Basin changed from shallow lake to fluvial (Liu et al., 2019; Liu et al., 2020) and led to the extensive development of terraces in the Weihe Basin after $\sim 1.2 \mathrm{Ma}(\mathrm{Hu}$ et al., 2017).

However, the age spectrum of sediments collected from Zhengzhou (HH02, ac of Figure 3; Yang et al., 2009) is quite different from the sediments of the upper Sm Fm. in the Sanmenxia Basin and Jinshaan Gorge but is similar to Zhongtiao Mountain. We believe that the construction of the Sanmenxia Reservoir could probably be the main reason for the blockage of sediment from the middle reach of the Yellow River transported downstream.

\section{Implications for the Environmental Change}

The integration of the Sanmenxia Basin and Weihe Basin until $2.8 \mathrm{Ma}$ indicates that the sediment before $2.8 \mathrm{Ma}$ in the
Sanmenxia Basin was a local record and could not be regarded as a record of paleo-Yellow River. This integration led to the decline of the Weihe Basin lake level, and the sediment from the western Qinling or Ordos Block transported by the Yellow River, Jing River, and Luo River could accumulate into the depocenter of the Weihe Basin. Therefore, the sediment with a young cluster of $\sim 200 \mathrm{Ma}$ increased remarkably after 2.6 Ma. The decline of the water table was also recorded in the variation of pollen (Tong et al., 2000; Zhao et al., 2018), ostracods (Wang et al., 2010), and paleosalinity (Liu et al., 2006), which was interpreted as a dry climate after 2.6 Ma. However, the decline may also be attributed to water outflow, thus creating a significant shift in the understanding of the paleoclimate evolution in this region. These landform changes led to changes in the provenance of the sediment, meaning that the Sanmenxia Basin after 2.8/2.6 Ma could not be used as an indicator of local paleoclimate.

\section{CONCLUSION}

1) Zircon chronology results revealed the drainage of Weihe Basin and Sanmenxia Basin began to connect at $\sim 2.8 \mathrm{Ma}$ and the middle reach of Yellow River finally formed at $\sim 1.0 \mathrm{Ma}$.

2) This study showed that the traversing time of the Sanmen Gorge was $\sim 1.0 \mathrm{Ma}$, and sediments from Jinshaan Gorge were deposited in the lower reaches of the Yellow River. However, the sediment character of the lower reaches varies obviously nowadays and could probably be attributed to dam construction.

3) The integration in the middle reaches of the Yellow River changed the regional landform and sediment provenance 
significantly and likely led to a mismatch between the deposition and regional paleoclimate.

\section{DATA AVAILABILITY STATEMENT}

The original contributions presented in the study are included in the article/Supplementary Material; further inquiries can be directed to the corresponding author.

\section{AUTHOR CONTRIBUTIONS}

JL performed the data analyses and wrote the article; PW performed the experiment; XC contributed to the conception of the study; WS and LS contributed significantly to analysis and

\section{REFERENCES}

Chen, Y., Yan, M., Fang, X., Song, C., Zhang, W., Zan, J., et al. (2017). Detrital Zircon U-Pb Geochronological and Sedimentological Study of the Simao Basin, Yunnan: Implications for the Early Cenozoic Evolution of the Red River. Earth Planet. Sci. Lett. 476, 22-33. doi:10.1016/j.epsl.2017.07.025

Chen, X., Dong, S., Shi, W., Zuza, A. V., Li, Z., Chen, P., et al. (2021). Magnetostratigraphic Ages of the Cenozoic Weihe and Shanxi Grabens in north china and Their Tectonic Implications. Tectonophysics 813 (6833), 228914. doi:10.1016/j.tecto.2021.228914

Craddock, W. H., Kirby, E., Harkins, N. W., Zhang, H., Shi, X., and Liu, J. (2010). Rapid Fluvial Incision along the Yellow River during Headward basin Integration. Nat. Geosci. 3, 209-213. doi:10.1038/ngeo777

Dickinson, W. R., Beard, L. S., Brakenridge, G. R., Erjavec, J. L., Ferguson, R. C., Inman, K. F., et al. (1983). Provenance of North American Phanerozoic Sandstones in Relation to Tectonic Setting. Geol. Soc. Am. Bull. 94, 222-235. doi:10.1130/0016-7606(1983)94<222:ponaps >2.0.co;2

Du, L., Yang, C., Wyman, D. A., Nutman, A. P., Lu, Z., Song, H., et al. (2016). 20902070Ma A-type Granitoids in Zanhuang Complex: Further Evidence on a Paleoproterozoic Rift-Related Tectonic Regime in the Trans-North China Orogen. Lithos 254-255, 18-35. doi:10.1016/j.lithos.2016.03.007

Du, L., Yang, C., Song, H., Zhao, L., Lu, Z., Li, L., et al. (2018). Petrogenesis and Tectonic Setting of 2. $2 \sim 2$. 1Ga Granites in Wutai Area, North China Craton. Acta Petrol. Sin. 34, 1154-1174 (in Chinese with English abstract).

Fu, J., Wang, S., Jiang, F., and Cai, Y. (2008). Age of Aeolian Deposition on the Highest Terrace in Yuanqu Basin and its Tectonic Significance. Quat. Sci. 28, 841-853 (in Chinese with English abstract).

Fu, J., Zhang, K., Ma, Z., Wang, S., and Wu, Y. (2013). The Terrace (T5 and T4) Formation since the Late Middle Pleistocene and its Implication in the through Cutting of the Middle Reach of Yellow River. Earth Sci. Front. 20, 166-181.

Gehrels, G. E., Yin, A., and Wang, X.-F. (2003). Detrital-zircon Geochronology of the Northeastern Tibetan Plateau. GSA Bull. 115, 881-896. doi:10.1130/00167606(2003) 115<0881:dgotnt $>2.0 . c 0 ; 2$

Gehrels, G. (2012). "Detrital Zircon U-Pb Geochronology: Current Methods and New Opportunities," in Tectonics of Sedimentary Basins: Recent Advances. Editor U. Chichester (New Jersey: Wiley-Blackwell), 47-62 (in Chinese with English abstract).

Han, H., Zhang, Y., and Yuan, Z. (2002). The Evolution of Weihe Down-Faulted basin and the Movement of the Fault Blocks. J. Seismol. Res. 25, 362-368 (in Chinese with English abstract).

He, M., Zheng, H., and Clift, P. D. (2013). Zircon U-Pb Geochronology and Hf Isotope Data from the Yangtze River Sands: Implications for Major Magmatic Events and Crustal Evolution in Central China. Chem. Geol. 360-361, 186-203. doi:10.1016/j.chemgeo.2013.10.020

$\mathrm{Hu}$, W., Yue, L., and Tian, X. (1993). On the Magnetostratigraphy of the Songjiabeigou Section, Youhe, Weinan. Geol. Shaanxi 11, 26-32 (in Chinese with English abstract). manuscript preparation; JH helped perform the analysis with constructive discussions.

\section{FUNDING}

This study was supported by the National Natural Science Foundation of China No. 42072242, and No. 41672203, Research Foundation of Education Bureau of Shaanxi Province, China (Grant No. 19JK0404).

\section{SUPPLEMENTARY MATERIAL}

The Supplementary Material for this article can be found online at: https://www.frontiersin.org/articles/10.3389/feart.2021.820674/ full\#supplementary-material

Hu, Z., Pan, B., Guo, L., Vandenberghe, J., Liu, X., Wang, J., et al. (2016). Rapid Fluvial Incision and Headward Erosion by the Yellow River along the Jinshaan Gorge during the Past 1.2 Ma as a Result of Tectonic Extension. Quat. Sci. Rev. 133, 1-14. doi:10.1016/j.quascirev.2015.12.003

Hu, Z., Pan, B., Bridgland, D., Vandenberghe, J., Guo, L., Fan, Y., et al. (2017). The Linking of the Upper-Middle and Lower Reaches of the Yellow River as a Result of Fluvial Entrenchment. Quat. Sci. Rev. 166, 324-338. doi:10.1016/ j.quascirev.2017.02.026

Jiang, F., Fu, J., Wang, S., Sun, D., and Zhao, Z. (2007). Formation of the Yellow River, Inferred from Loess-Palaeosol Sequence in Mangshan and Lacustrine Sediments in Sanmen Gorge, China. Quat. Int. 175, 62-70. doi:10.1016/ j.quaint.2007.03.022

Kong, P., Jia, J., and Zheng, Y. (2014). Time Constraints for the Yellow River Traversing the Sanmen Gorge. Geochem. Geophys. Geosyst. 15, 395-407. doi:10.1002/2013gc004912

Licht, A., Pullen, A., Kapp, P., Abell, J., and Giesler, N. (2016). Eolian Cannibalism: Reworked Loess and Fluvial Sediment as the Main Sources of the Chinese Loess Plateau. Geol. Soc. Am. Bull. 128, B31371-B31375. doi:10.1130/b31375.1

Liu, Z., and Zhou, L. (2015). The Cenozoic Tectonic and Sedimentary Framework and Preliminary Study on the Hydrocarbon Accumulation Potential of the Weihe basin. J. Fuzhou Univ. (Natural Sci. Edition) 43, 708-714 (in Chinese with English abstract).

Liu, H., Xue, X., and andLi, Y. (2006). Calculation on the Paleosalinity of the Ancient Sanmen Lake in the Weinan Area of Weihe River Basin. J. Northwest Univ. (Natural Sci. Edition) 36, 112-114 (in Chinese with English abstract). doi:10.3799/dqkx.2020.112

Liu, J., Chen, X., Shi, W., Chen, P., Zhang, Y., Hu, J., et al. (2019). Tectonically Controlled Evolution of the Yellow River Drainage System in the Weihe Region, North China: Constraints from Sedimentation, Mineralogy and Geochemistry. J. Asian Earth Sci. 179, 350-364. doi:10.1016/j.jseaes.2019.05.008

Liu, J., Chen, X., Wang, P., and Li, T. (2020). Sedimentary Characteristics, Provenance and Tectonic Significance of the Sanmen Formation in WeiheSanmenxia Basin. Earth Sci. 45, 2673-2683 (in Chinese with English abstract). doi:10.3799/dqkx.2020.112

Nie, J., Horton, B. K., Saylor, J. E., Mora, A., Mange, M., Garzione, C. N., et al. (2012). Integrated Provenance Analysis of a Convergent Retroarc Foreland System: U-Pb Ages, Heavy Minerals, Nd Isotopes, and sandstone Compositions of the Middle Magdalena Valley basin, Northern Andes, Colombia. EarthScience Rev. 110, 111-126. doi:10.1016/j.earscirev.2011.11.002

Nie, J., Stevens, T., Rittner, M., Stockli, D., Garzanti, E., Limonta, M., et al. (2015). Loess Plateau Storage of Northeastern Tibetan Plateau-Derived Yellow River Sediment. Nat. Commun. 6, 700-705 (in Chinese, with English summary). doi:10.1038/ncomms9511

Pan, B., Wang, J., Gao, H., Chen, Y., Li, J., and Liu, X. (2005). Terrace Dating as an Archive of the Run-Through of the Sanmen Gorges. Prog. Nat. Sci., 700-705.

Pan, B., Hu, Z., Wang, J., Vandenberghe, J., Hu, X., Wen, Y., et al. (2012). The Approximate Age of the Planation Surface and the Incision of the Yellow River 
Palaeogeogr. Palaeoclimatol. Palaeoecol. 356-357, 54-61. doi:10.1016/ j.palaeo.2010.04.011

Peng, P., Yang, S., Su, X., Wang, X., Zhang, J., and Wang, C. (2017). Petrogenesis of the 2090 Ma Zanhuang Ring and Sill Complexes in North China: A Bimodal Magmatism Related to Intra-continental Process. Precambrian Res. 303, 153. doi:10.1016/j.precamres.2017.03.015

Shang, Y., Nian, X., Zhang, W., and Wang, F. (2021). Yellow River's Contribution to the Building of Yangtze Delta during the Last 500 Years-Evidence from Detrital Zircon U-Pb Geochronology. Geophys. Res. Lett. 48, e2020G-e91896G. doi:10.1029/2020GL091896

Stevens, T., Carter, A., Watson, T. P., Vermeesch, P., Andò, S., Bird, A. F., et al. (2013). Genetic Linkage between the Yellow River, the Mu Us Desert and the Chinese Loess Plateau. Quat. Sci. Rev. 78, 355-368. doi:10.1016/ j.quascirev.2012.11.032

Sun, J. (2005). Long-term Fluvial Archives in the Fen Wei Graben, central China, and Their Bearing on the Tectonic History of the India? Asia Collision System during the Quaternary. Quat. Sci. Rev. 24 (10-11), 1279-1286. doi:10.1016/ j.quascirev.2004.08.018

Tong, G., Wu, X., and Chen, Y. (2000). Palynoevents since Late Cenozoic in Weihe Valley and Climate Changes. J. Geomech. 6, 18-65 (in Chinese, with English abstract).

Vermeesch, P. (2012). On the Visualisation of Detrital Age Distributions. Chem. Geol. 312-313, 190-194. doi:10.1016/j.chemgeo.2012.04.021

Wang, S., Jiang, F., and Wu, X. (1999). A Study on the Age of Sanmen Group in Sanmenxia Area. J. Geomech. 5, 65-71 (in Chinese, with English abstract).

Wang, S., Wu, X., Zhang, Z., Jiang, F., Xue, B., Tong, G., et al. (2002). Sedimentary Records of Environmental Evolution in the Sanmen Lake Basin and the Yellow River Running through the Sanmenxia Gorge Eastward into the Sea. Sci. China Ser. D-Earth Sci. 45, 595-608 (in Chinese with English abstract). doi:10.1360/ 02yd9061

Wang, S., Jiang, F., Wu, X., Wang, S., and Tian, G. (2004). The Connotation and Significance of Sanmen Formation. Quat. Sci. 24, 116-123.

Wang, Z., Wang, P., and Wang, X. (2010). Study on the Neogene-Quaternary Ostracoda Fossils of Sanmen Formation in Songjiabeigou, Weinan, Shaanxi. J. Xi'an Shiyou Univ. (Natural Sci. Edition) 1, 10 (in Chinese with English abstract).

Wang, S., Jiang, F., Fu, J., Li, C., Cai, Y., Yao, H., et al. (2013). Some Knowledge of the Formation of the Yellow River. Quat. Sci. 33, 705-714. doi:10.3724/ sp.j.1140.2013.05053

Wang, S., Fu, B., Piao, S., Lü, Y., Ciais, P., Feng, X., et al. (2016). Reduced Sediment Transport in the Yellow River Due to Anthropogenic Changes. Nat. Geosci. 9 (1), 38-41. doi:10.1038/ngeo2602

Xiao, G., Sun, Y., Yang, J., Yin, Q., Dupont-Nivet, G., Licht, A., et al. (2020). Early Pleistocene Integration of the Yellow River I: Detrital-Zircon Evidence from the North China Plain. Palaeogeogr. Palaeoclimatol. Palaeoecol. 546, 109691. doi:10.1016/j.palaeo.2020.109691

Xue, T. (1996). Trusting in Traditional Cures. Nature 379, 110. doi:10.1038/ $379110 \mathrm{a} 0$

Yang, S., Cai, J., Li, C., and Deng, B. (2001). New Discussion about the RunThrough Time of the Yellow River. Mar. Geol. Quat. Geol. 21, 15-20 (in Chinese with English abstract).

Yang, J., Gao, S., Chen, C., Tang, Y., Yuan, H., Gong, H., et al. (2009). Episodic Crustal Growth of North China as Revealed by U-Pb Age and Hf Isotopes of Detrital Zircons from Modern Rivers. Geochim. Cosmochim. Acta 73, 2660-2673. doi:10.1016/j.gca.2009.02.007
Zhai, M., and Peng, P. (2007). Paleoproterozoic Events in the North China Craton. Acta Petrol. Sin. 23, 2665-2682 (in Chinese, with English abstract).

Zhai, M.-G., and Santosh, M. (2011). The Early Precambrian Odyssey of the North China Craton: A Synoptic Overview. Gondwana Res. 20, 6-25. doi:10.1016/ j.gr.2011.02.005

Zhang, X., He, M., Wang, B., Rits, S. D., and Zheng, H. (2018). Provenance Study of the Sediments in Wei River Using the Detrital Zircon U-Pb Dating. Mar. Geol. Quat. Geol. 38, 202-211. doi:10.16562/j.cnki.0256-1492.2018.01.021

Zhang, X., He, M., Wang, B., Clift, P., Rits, D., Zheng, Y., et al. (2019). Provenance Evolution of the Northern Weihe Basin as an Indicator of Environmental Changes during the Quaternary. Geol. Mag. 156, 1915-1923. doi:10.1017/ s0016756819000244

Zhang, H., Lu, H., Zhou, Y., Cui, Y., He, J., Lv, H., et al. (2021). Heavy mineral Assemblages and $\mathrm{U} \mathrm{Pb}$ Detrital Zircon Geochronology of Sediments from the Weihe and Sanmen Basins: New Insights into the Pliocene-Pleistocene Evolution of the Yellow River. Palaeogeogr. Palaeoclimatol. Palaeoecol. 562, 110072. doi:10.1016/j.palaeo.2020.110072

Zhang, H. (2008). The Chronological Study on U-Pb Dating of Modern River Detrital Zircon in North piedmont of Qinling and its Geological Indication. Northwest University, 74.

Zhao, L., Lu, H., and Tang, L. (2018). Cenozoic Palynological Records and Vegetation Evolution in the Weihe Basin, Central China. Quat. Sci. 38, 1083-1093 (in Chinese with English abstract).

Zheng, H., Huang, X., Ji, J., Liu, R., Zeng, Q., and Jiang, F. (2007). Ultra-high Rates of Loess Sedimentation at Zhengzhou since Stage 7: Implication for the Yellow River Erosion of the Sanmen Gorge. Geomorphology 85, 131-142. doi:10.1016/ j.geomorph.2006.03.014

Zheng, H., Clift, P. D., He, M., Bian, Z., Liu, G., Liu, X., et al. (2020). Formation of the First Bend in the Late Eocene Gave Birth to the Modern Yangtze River, China. Geology 49, 35-39. doi:10.1130/g48149.1

Zhu, Z. (1989). The Formation of Terraces in the Middle Reach of the Yellow River and the Drainage System Evolution. Acta Geograph. Sin. 61 (4), 429-440 (in Chinese with English abstract).

Conflict of Interest: XC was employed by China Railway First Survey \& Design Institute Group Co., Ltd.

The remaining authors declare that the research was conducted in the absence of any commercial or financial relationships that could be construed as a potential conflict of interest.

Publisher's Note: All claims expressed in this article are solely those of the authors and do not necessarily represent those of their affiliated organizations, or those of the publisher, the editors and the reviewers. Any product that may be evaluated in this article, or claim that may be made by its manufacturer, is not guaranteed or endorsed by the publisher.

Copyright (c) $2022 \mathrm{Liu}$, Wang, Chen, Shi, Song and Hu. This is an open-access article distributed under the terms of the Creative Commons Attribution License (CC BY). The use, distribution or reproduction in other forums is permitted, provided the original author(s) and the copyright owner(s) are credited and that the original publication in this journal is cited, in accordance with accepted academic practice. No use, distribution or reproduction is permitted which does not comply with these terms. 